\title{
Patterns of Party Change in Central and Eastern Europe, 1990-2015
}

\author{
Raimondas Ibenskas \\ University of Southampton
}

Allan Sikk

University College London 


\begin{abstract}
While parties in many new democracies frequently split, merge, change labels, and make and break electoral alliances, comparative systematic research on how these changes are related to each other is limited. This study addresses this gap by conceptualizing change as a result of intra-party conflicts, conflicts in or consolidation of existing electoral alliances, and the formation of new alliances and mergers. We develop measures for each type of change using an original dataset that covers almost 800 party-electoral term dyads in 11 countries in Central and Eastern Europe in the period between 1990 and 2015. Our findings contradict the idea of party change as a uni-dimensional phenomenon. Instead we find that exits from existing electoral alliances, their consolidation through mergers, and the formation of new alliances and mergers are moderately related to each other, but not with intra-party splits. Thus, parties and their alliances structure political competition in Central and Eastern Europe relatively well. Our findings also suggest that negative consequences of party change on representation and accountability are limited, as under the relative absence of multiple and nearly simultaneous changes in party identity the electorate should be able to follow party evolution.
\end{abstract}

Keywords: political party change, Central and Eastern Europe, party merger, electoral alliance, party split.

We would like to thank Andreas Bågenholm, Sophie Blombäck, Adriana Bunea, Andrea Ceron, Ladislav Csabada, Liutauras Gudžinskas, Matthias Haber, Ann-Kristin Kölln, Vitalis Nakrošis, Jonathan Polk, the participants in the workshop on intra-party party politics at the University of Gothenburg in September 2015, and three anonymous reviewers and the editors of Party Politics for their valuable comments. While doing this research, the first author benefited from the funding from the Marie Sklodowska-Curie Actions Programme (IntraEuropean Individual Fellowship Grant No 330446 PARTYINSTABILITY). This financial support is gratefully acknowledged. 


\section{Introduction}

Political parties and party systems are crucial institutions for the functioning of a modern representative democracy. Among other functions, political parties aggregate and represent various interests in policy-making and ensure the accountability of democratic government to voters. The ability of parties to fulfil these functions varies across democracies and time periods though. The literature on third wave democracies, in particular, has called into question parties' capability to assure voter representation, electoral accountability and effective governance. One of the key weaknesses of parties in young democracies is their instability. The change in party alternatives occurs in various ways: parties do not simply only enter and exit electoral competition, but they also split, merge, and form and dissolve electoral coalitions. ${ }^{1}$ These complex changes of identity have important consequences on democracy: they may change the levels of party system fragmentation, undermine voters' representation by confusing them about parties' policy positions, impede the formation of stable partisan identities, and prevent voters from holding parties accountable. ${ }^{2}$ Consequently, the literature has recently made an important effort in conceptualizing these types of party change and analyzing their patterns, causes, and consequences (Casal-Bertoa et al., 2015; Ceron, 2015b; Golder, 2006; Ibenskas, 2016a; Kaminski, 2001; Litton, 2015; Marinova, 2015).

However, an important gap in this scholarship, addressed by the present study, concerns the lack of theoretical and empirical analysis of the relationship between different types of party instability. Parties may split, merge, or form and dissolve alliances (nearly) simultaneously. Alternatively, each of these types of party change may occur in isolation from the others. Implications for democracy are substantively different depending on which pattern prevails. Specifically, if different party transformations occur in close temporal proximity, party alternatives would change almost unrecognizably between elections. Voters would find

\footnotetext{
${ }^{1}$ In this study, 'electoral coalitions' and 'electoral alliances' are used interchangeably to refer to joint candidate lists in national elections, as discussed in the section on data and measurement.

${ }^{2}$ Other consequences may be more positive: for example, electoral coalitions and mergers may reduce the share of wasted vote and increase the clarity of government alternatives to the electorate.
} 
it very challenging to learn about parties' policy positions and therefore vote according to their policy preferences. Similarly, such complex transformations of party identity would decrease voters' ability to punish government parties for poor performance and/or to identify credible alternatives among the parties in opposition. In contrast, representation and accountability are less likely to be undermined if parties do not experience multiple transformations of different types simultaneously. As the basic contours of the party system remain unchanged between elections, the electorate is more likely to keep track of party evolution.

The relationship between different types of party transformations also has important implications on how we understand political competition in new democracies. ${ }^{3}$ This is because some of these changes, especially party splits, are a result of intra-party conflicts. The formation and dissolution of electoral alliances and mergers on other hand is largely an outcome of inter-party competition and cooperation. If we observe that these different types of party change tend to occur together, it would suggest that parties' ability to structure political competition is low. Party boundaries can be easily crossed by individual politicians or their groups, which suggests that they rather than parties are the main building blocks of political competition (Birch, 2003; Rakner et al., 2007).

An additional complexity is that many formations in young democracies, while formally electoral alliances or blocs, in fact can also be considered as parties due to relatively high levels of their institutionalization. Indeed, major cross-national comparative databases on political parties, such as the Chapel Hill expert survey on parties' positions (Bakker et al., 2015) or the Manifesto Project database, include multiple electoral alliances. Several examples are the Coalition for Bulgaria and the Union of Democratic Forces (which was a coalition until the mid-1990s) in Bulgaria, the Unity coalition and the Union of Greens and Farmers in Latvia, the Solidarity Electoral Action and the Left and Democrats in Poland, and the Slovak Democratic Coalition in Slovakia. The present study sheds light on the stability, longevity and, more generally, 'partyness' of such alliances.

\footnotetext{
${ }^{3}$ Our approach here is related but distinct from Franzmann (2011), who conceptualizes party competition as interactions that include both cooperation and contestation.
} 
To address this complexity of party competition in young democracies, we focus on the co-occurrence of the change in party identities as a result of conflicts and cooperation at three levels: intra-party, intra-coalition, and inter-party. First, at the intra-party level, we examine the presence (absence) of party splits as an indication of a conflict (cooperation) between various actors in the party. Second, at the coalitional level, we conceptualize conflict as the dissolution of existing alliances, and the persistence of cooperation as the survival of these alliances or their consolidation through full-blown party mergers. Third, we capture the formation of cooperation arrangements by previous competitors as the creation of alliances and merged parties by the parties that previously did not cooperate in electoral coalitions.

We measure these patterns of conflict and cooperation by drawing on a new database on party change (designed specifically for this study) in 11 countries in Central and Eastern Europe in 73 electoral terms in the period between 1990 and 2015. The dataset considers parties with at least 1 percent of the vote, and the total number of party-electoral term dyads is almost 800 . This substantial data collection effort provides an important empirical contribution to understanding the development of parties and party systems in Central and Eastern Europe.

In the next section, we discuss the linkage between intra-party, intra-coalition, and interparty conflict and cooperation in new democracies, and the ways in which party change helps us to understand this link. We then address the measurement issues. The final two sections discuss the results of the analysis and their implications.

\section{Intra-party and inter-party conflict and cooperation in new democracies}

The study of intra-party politics is a diverse and rapidly developing field of research that includes a number of theoretical perspectives and empirical approaches (Giannetti and Benoit, 2009). This variety is a result of the importance and complexity of contemporary 
political parties, in which internal party disagreements and tensions may arise for a variety of reasons and at different levels of party organization. What these multiple streams of research share however is their focus on the level of the heterogeneity of the behaviour and preferences of internal party actors, both individuals, such as legislators, activists and rank-and-file members, and collective ones, such as factions and tendencies.

One important reason why internal party politics should be studied is that it affects whether these various actors remain in the party. Indeed, exit (Hirschman, 1970) is an extreme form of internal party disunity. It can take various forms, including the defection of legislators to other parties (Ceron, 2015a; Desposato, 2006; Laver and Benoit, 2003; Mershon, 2014) and the formal withdrawal of activists from the party (Kölln and Polk, 2015; Scarrow, 2015). This research complements these important and relevant approaches by focusing on the defection of intra-party factions, groups or individual politicians that lead to the emergence of new parties. Such party splits (also referred to as fission and breakaways in this study) are important because they may change the dynamics in the party system by leading to the emergence of a successful splinter party and/or the electoral collapse of a parent party (Hug, 2001; Ibenskas, 2014b). Furthermore, splits of government parties also threaten government stability (Ceron, 2015b).

So far, most advanced theoretical and empirical work on party splits has focused on established democracies (Ceron, 2015b; Giannetti and Laver, 2001). However, party fission has long been identified as an important characteristic of parties and party systems in young democracies (Lewis, 2000; Millard, 2004; Olson, 1998; Rose and Munro, 2003; Sikk, 2005; Spirova, 2007; Szczerbiak, 2001), and there is evidence to suggest that they are indeed on average more prevalent in these countries in comparison to older Western democracies (Ibenskas, 2014b; Marinova, 2015).

A systematic study of party fission in young democracies is challenging though. This is not only because the fluidity of parties in many of these countries creates substantial data collection problems, but also because the concept of party itself is less well established. One 
issue is that many so-called parties are actually electoral alliances or blocs that consist of multiple parties and other groups. Although such blocs exist in older democracies as well, as the analysis of the German Christian Democrats by Greene and Haber (2015) in this special issue demonstrates, these blocs tend to be rare and they have well-defined and stable memberships. In contrast, electoral alliances and blocs are an important feature of party landscape in almost every new democracy. For example, Ibenskas (2016b) finds that on average 1.8 joint candidate lists competed in an election in Central and Eastern European countries. These alliances also vary greatly in terms of their stability and institutionalization. While some are dissolved after elections (Millard, 2004), others have persisted for a long time (e.g. the coalition between Fidesz - Hungarian Civic Alliance and the Christian Democratic Party in Hungary or the Green and Farmers' Union in Latvia) or developed intricate procedures and rules of cooperation (e.g. the Union of Democratic Forces in Bulgaria, the Democratic Convention in Romania, and the Solidarity Electoral Action in Poland in the 1990s). Given the longevity and institutionalization of these alliances, their termination by constituent parties may be considered (and have been considered in the literature) as party splits. Furthermore, anecdotal evidence suggests that some of these intra-coalition conflicts overlap with splits of their constituent parties, which would require a systematic study of party fission to consider both intra-party and intra-coalition levels. ${ }^{4}$ However, more systematic evidence on the relationship between party and coalition stability is not available in the literature.

An additional complication arises because many observers of the politics of new or young democracies consider splits of parties or dissolutions of alliances as being intrinsically related to the formation of new alliances or permanent party mergers (Mair, 1997). According to this view, in the context of limited ideological structuration of party competition, weak voter partisanship, and low party institutionalization, parties or their alliances are just temporary

\footnotetext{
${ }^{4}$ For example, the dissolution of the ethnic Russian alliance For Human Rights in a United Latvia (PCTVL) in 2003-2004 was followed by the splits of two of these parties, leading to the formation of a splinter party.
} 
and expedient formations, and as such are of minor importance in understanding political competition. Instead, individual politicians are the main building blocs of political competition in this 'floating party system' (Birch, 2003; Millard, 2004; Rose and Shin, 2001; Szczerbiak, 2001). The party landscape can therefore be easily transformed through the dissolution of existing parties and alliances and the formation of new coalitions and merged parties if these re-combinations help individual politicians to reach office (Rakner et al., 2007).

While the 'floating party system' view quite precisely describes political competition in many democracies in Africa, Latin America, South-East Asia and Eastern Europe, it is more controversial with regard to countries in Central and Eastern Europe. One the one hand, it has been challenged by a number of studies that find quite stable and structured party competition in most Central and Eastern European countries following the chaotic decade of the 1990s (Bakke, 2010). Many states in the region have adopted party regulation (Casal Bértoa and van Biezen, 2014) that limited the participation of non-party actors (for example, social movements or trade unions) in elections, thus eliminating some fuzzy alliances and groups. Furthermore, party competition based on ideological grounds has emerged (Kitschelt et al., 1999; Rohrschneider and Whitefield, 2012; Rovny and Polk, 2015) and at least some parties established relatively strong party organizations (Gherghina, 2014; Ibenskas, 2014a; Tavits, 2013). On the other hand, the strength of membership organizations remains weaker in Central and Eastern Europe than in Western Europe (Van Biezen et al., 2012), the level of party organizational change is higher (Marinova, 2015), and all countries in the region continue to experience high levels of new party entry, including the emergence of centrist parties with fuzzy ideologies (Bågenholm, 2013; Hanley and Sikk, 2014; Pop-Eleches, 2010; Sikk, 2012).

This research makes a contribution to this debate on the strength of parties in new democracies by focusing on the extent to which conflicts and cooperation at three levels (intra-party, coalition, and party systemic) overlap. Specifically, at the intra-party level, 
we examine the presence (absence) of fission as an indication of a conflict (cooperation) between various groups in the party. At the intra-coalition level, we conceptualize conflict as the dissolution of existing alliances, and the persistence of cooperation as the continuation of these alliances or their consolidation through full-blown party mergers. Finally, we capture the formation of cooperation arrangements by previous competitors as the creation of new alliances and merged parties by the parties that previously did not cooperate in electoral coalitions.

According to the approach that emphasizes high instability of parties and party systems in Central and Eastern Europe, the patterns of cooperation and conflict should substantially overlap at all three levels, thus making intra- and inter-party cooperation and conflict indistinguishable. This approach suggests the following hypothesis:

Hypothesis 1: Intra-party and intra-coalition conflict and inter-party cooperation are likely to co-occur.

If, however, parties in Central and Eastern Europe are relatively strong institutions, the patterns of conflict and cooperation at the intra-party, coalition and party system levels, while more frequent than in most Western democracies, should occur independently from each other. This forms an alternative hypothesis of the present research.

\section{Data and measurement}

We analyse party change in 11 current EU member states in Central and Eastern Europe from the first democratic elections until $2015 .{ }^{5}$ Our unit of observation is party-in-electoral term (between $t$ and $t+1$ ), but we also examine the relationship between different types of change in individual parties across several elections.

As we are interested in patterns of intra- and inter-party conflict and cooperation, we only include parties that persisted throughout the term. This includes parties that joined an

\footnotetext{
${ }^{5}$ We exclude the 1990 elections in the Baltic states that were still part of the Soviet Union and politics there was more clearly dominated by the confrontation between democratic movements and communist parties than in other founding elections. Also, we only have incomplete data for these elections.
} 
electoral alliance or underwent a merger, but excludes new parties and those that disappeared from electoral scene. We include all parties that received at least one percent of the vote in $t$, regardless of their support in $t+1$. Hence, we include parties that lost most of their support in $t+1$, but were relevant in $t$ - a fairly common occurrence in Central and Eastern Europe. In total, we study 796 parties-in-electoral-term in 73 electoral terms. ${ }^{6}$

To capture conflict and cooperation at intra-party, intra-coalition, and inter-party level, we identify six types of party change: split, exit from an electoral coalition, exit label change, the consolidation of an electoral alliance through a merger, entry into a new electoral coalition or merger and entry label change. We use the term electoral coalitions (interchangeably with alliances) for joint candidate lists, excluding weaker forms of electoral cooperation, such as public commitments to govern together (Golder, 2006), where parties give up very little autonomy. Most countries included in our study used PR or mixed electoral systems. For the only election in which a majoritarian system was used (Croatia 1990), electoral coalition is defined as joint candidates in single-member districts.

\section{Intra-party conflict}

We define split as the foundation of a new party (splinter party) by politician(s) formerly affiliated with another party. We only include splits after which the splinter party contested an election independently or as part of an electoral coalition, thus excluding switching of individual members or splinter factions between parties. In total, we record 154 cases of splits, affecting 19 percent of all party-electoral term dyads.

\section{Intra-coalition conflict and cooperation}

Intra-coalition conflict and cooperation takes three forms: exit from an electoral coalition, exit label change and merger. An exit from coalition entails that a party no longer shares an

\footnotetext{
${ }^{6}$ We only consider elections to the lower chamber. The estimated vote share of parties in electoral coalitions is the product of (a) the coalition's vote share and (b) the proportion of coalition's seats won the party. For coalitions with no seats, we assume equal votes for constituent parties.
} 
alliance with at least one of its coalition partners in previous election. For two-party alliances this means that the parties compete independently or in different coalitions. For alliances of more than two parties, an exit is coded if at least one of these parties leaves the alliance by the next election. We recorded 188 exits, affecting 24 percent of parties-in-electoral-term.

While exit from coalition focusses on changes in coalition membership, exit label change contrasts party labels (registered names) with their electoral labels (incl. coalition names). Party label change has not been extensively studied (but see Kim and Solt 2015), but electoral label change in Central and Eastern Europe appears to be closely related to intra-coalition conflict. Alliances seldom use names of their constituent parties - Civic Platform (Poland 2001) was a rare exception as it was effectively an alliance, including candidates of the Conservative People's Party. More often, they combine names of its constituent parties (e.g. 'Working for Lithuania: Lithuanian Social Democratic Party and New Union' in 2004) or adopt a unique name (e.g. 'Unity' in Latvia 2012, composed of New Era, Civic Union and Society for Different Politics). In such cases, as parties move in and out of electoral coalitions, their electoral labels change.

Exit label change can be seen as a different form of exit from an electoral alliance, when: (1) party's electoral label changes between elections but (2) its electoral label in $t$ does not match the party label in $t$ and $t+1$. The logic behind the coding is the following. First, if party label differs from its electoral label, it must have been part of an electoral alliance - e.g. none of the parties in 'Working for Lithuania' or 'Unity' shared a label with the coalition. Second, if electoral label changes between elections, the party must have left the alliance, either to compete in elections alone or in alliance with other parties. For example, the Lithuanian Social Democrats and the New Union competed under their own labels in 2008, after forming a coalition in 2004. Still, party's electoral label may also change if members of an alliance merge, adopting its label - e.g. the members of 'Unity' merged into a single party (also called 'Unity') before the next election. Such cases, where the party label in $t+1$ matched its electoral label in $t$, are not coded as exits. We recorded 195 of exit label changes 
in our dataset. ${ }^{7}$

While exit from a coalition and exit label change reflect intra-coalition conflict, a merger represents consolidation. We define it as a merger of two or more parties that in previous election were joint members of an electoral alliance. We record 74 cases of a party participating in such a merger, affecting 9 percent of our sample.

\section{Inter-party cooperation}

Inter-party cooperation occurs if during an electoral period a party joins a new electoral alliance or a new merged party. ${ }^{8}$ We define an electoral coalition as new in $t+1$, if it includes at least one party that did not coalesce with other parties in $t$. Similarly, a new merger involves at least one party that was not in electoral coalition with other constituent parties in the preceding election. Thus, we exclude from the definition merged parties strictly based on electoral alliances in the preceding election. If more than two parties form an alliance or merge before an election, then at least one of them must have contested the previous election independently or in a different alliance than other constituent parties of the coalition or merger. In total, we recorded 324 new coalition entries or mergers.

New inter-party cooperation can also take the form of entry label change. As discussed above, changes in electoral labels provide an alternative way to identify the formation of new coalitions to directly tracking alliance membership. Entry label change occurs if: (1) party's label at the time of election $t+1$ does not match its electoral label, and (2) its electoral label has changed between elections. The first condition implies that the party contested

\footnotetext{
${ }^{7}$ This rule complements changes in alliance membership in two ways. First, it does not consider as exits cases where a party that leaves an alliance is too insignificant for the coalition to change its label. For example, the Bulgarian Union of Democratic Forces retained the label between the 1991 and 1994 elections, even though it lost some of its constituent parties. Second, we can capture cases when a party was a member of an electoral alliance that included formations and individuals insufficiently organized to be considered parties or too small to be included in the dataset. For example, in 1992, the Czech Communist party formed a 'Left Bloc' with a minuscule 'Democratic Left', but reverted to its own party label by the 1996 parliamentary election. The change in its electoral label reflects a change in coalitional affiliation, which would otherwise go unnoticed, as 'Democratic Left' had too low support to be included in the dataset.

${ }^{8} \mathrm{~A}$ more nuanced analysis would consider mergers and new coalitions separately, but we combine them here because our main goal is to capture all new forms of inter-party cooperation.
} 
election in $t+1$ as part of an alliance. The second condition implies that in $t$ the party either ran independently or under a different alliance label than its electoral label in $t+1$. In combination, they indicate that the party either joined a new coalition or switched coalitions during an electoral term. ${ }^{9}$ The total number of entry label changes was 274.

\section{Empirical analysis}

Our empirical analysis consists of three parts. First, we analyze the co-occurrence of six types of party change within a single electoral term. Second, we focus on how they correlate at the level of individual party. Third, we interpret and contextualize these patterns by emphasizing the effects of three factors suggested in the literature - party size, the age of democracy, and electoral institutions.

\section{Conflict and cooperation within a single legislative term}

We first examine the distribution of the number of changes for each party-in-electoral term in our sample (Figure 1). On average, a party experiences 1.5 change events in an electoral term. The distribution is skewed to the right with the median number of events being 1.0. Thus, almost a half of observations in the sample are characterized by more than one event. Close to 25 percent experienced more than two events of change.

[Figure 1 about here]

Table 1 flashes out the patterns of the relationship between individual forms of change through pairwise correlation coefficients. Unsurprisingly, given that they capture the same theoretical concepts, the relationship between entries into electoral coalitions and entry label changes and between exits from coalitions and exit label changes is strongest: correlation

\footnotetext{
${ }^{9}$ It is also possible that the alliance label changed between elections, while the party remained its member. We argue that such a change in alliance label indicates a substantive change and such an alliance ought to be seen as new.
} 
coefficients exceed 0.8 in both cases. The association between intra-coalition conflict and new inter-party cooperation is moderately strong. More specifically, the pairwise correlations between the variables that capture exit and exit label change and entry and entry label change range between 0.3 and 0.5 . Furthermore, there is only a weak relationship between intra-coalition cooperation (mergers) on the one hand and intra-coalition conflict and interparty cooperation on the other hand (correlation coefficients vary between 0.15 and 0.3 ). Finally, the correlation between party fission and the remaining five variables is particularly low, with none of the coefficients exceeding 0.1 .

\section{[Table 1 about here]}

We find similar patterns in the exploratory factor analysis of change (see Table 2). Two factors are extracted based on the scree plot. The first factor is most related to the forms of change that represent inter-party cooperation, namely, the entry into a new coalition or merger and entry label change. Intra-coalition conflict and cooperation load on this factor weakly. Conversely, the second factor is strongly related to exits from electoral alliances and exit label changes, but entry label change and mergers are also somewhat associated with this factor. The loadings of splits on either of these factors are low.

[Table 2 about here]

Multiple Correspondence Analysis (MCA) allows us to uncover the dimensionality of our data more fully. We interpret the first four dimensions from the MCA solution. They have eigen values of $0.36,0.20,0.17$ and 0.16 , meaning that they all either exceed or are very close to the threshold of 0.167 that establishes whether an axis is sufficiently important to be interpreted. ${ }^{10}$ In contrast, the fifth factor has an eigen value of only 0.08 .

The results of MCA are summarized in Figure 2, which presents, in two separate plots, the coordinates of each of the 12 variable categories (i.e. dichotomous categories for the

\footnotetext{
${ }^{10}$ Greenacre $(2007,140)$ recommends to interpret dimensions with eigen values above the ratio between 1 and the number of variables ( 6 in the present analysis).
} 
presence or absence of six variables of party change) on all four dimensions. ${ }^{11}$ The first two dimensions capture the exit from existing alliances (Dimension 1) and the formation of new coalitions and merged parties (Dimension 2). Thus, on the first dimension ( $\mathrm{x}$ axis in Figure 2), the scores of the categories that indicate the exit from alliances have high positive values (above 1) while the categories that measure the absence of the termination of alliances have relatively high negative values. The scores of all other variable categories on this dimension are close to 0. Similarly, the second dimension (y axis in Figure 2) contrasts the categories that indicate the participation of the party in a new electoral coalition or merged party and the absence of such cooperation.

[Figure 2 about here]

The remaining two dimensions can be easily interpreted as the presence of intra-party conflict, as captured by party fission (Dimension 3), and the consolidation of an existing alliance through a merger (Dimension 4). No other categories have high scores on these two axes of the MCA solution. This confirms the findings in Table 1 about the low correlation of these two variables with the remaining measures of party change.

Overall, the evidence suggests that forms of change occur largely independently from each other. This evidence contradicts Hypothesis 1, which proposed the uni-dimensional pattern of change.

\section{Conflict and cooperation across legislative terms}

While the previous sub-section suggests that intra-party conflict, intra-coalition conflict and cooperation and new inter-party cooperation is unlikely to occur in a single term, it is possible that individual parties experience these changes at different points in their lifetime. To aggregate our data at the party level, we compute the share of electoral terms (from the total number of periods in which the party was present) in which the party experienced each

\footnotetext{
${ }^{11}$ To increase the interpretability of the results, we apply varimax rotation to the original MCA solution.
} 
form of change. In this analysis we exclude all parties that entered our sample only once because their electoral support and institutionalization is substantially lower than that of their more persistent competitors. Given the high number of these short-lived parties (145 or $45 \%$ of the total), their inclusion in the analysis could severely bias our results.

Looking at the remaining 179 parties, we find that the average number of change events per party (5.1) is higher than that per party-in-electoral-term (Figure 1). The overwhelming majority of parties (92\%) experienced at least one change event in their lifetimes. The median is 4 events. A non-negligible number of parties experienced more than 10 events. Two parties in Croatia (the Peasant Party and the People's Party) had the highest number of events (19 each) - on average, more than 3 events per electoral term.

Table 3 also indicates a somewhat stronger relationship between different forms of change than reported in the previous sub-section. Specifically, pairwise correlations between exit, exit label change, entry and entry label are are all relatively strong. However, the association between intra-coalition cooperation (mergers) on the one hand and intra-coalition conflict and inter-party cooperation on the other hand is weak with the exception of the moderate correlation between entry and mergers. Also, intra-party conflict does not correlate much with any other forms of change in line with the results in Table 1.

[Table 3 about here]

Exploratory factor analysis (Table 4) suggests that change across terms is charaterized by either one or two dimensions. In the one-dimensional solution, intra-coalition conflict and new inter-party cooperation load highly on the extracted factor, mergers are associated with it weakly, and splits barely at all. In the two-dimensional solution, the first factor captures new inter-party cooperation and, to a lower extent, intra-coalition conflict and cooperation. The second factor is associated with intra-coalition conflict and one of the variables of new inter-party cooperation (entry label change). Splits do not load on any of these factors.

[Table 4 about here] 
The uncovered relationship between inter-party cooperation on the one hand and intracoalition conflict and, less so, cooperation on the other is partially expected. Parties by definition need to enter coalitions before they can exit or consolidate them through mergers. Still, the strength of these relationships suggest that most electoral coalitions are either dissolved or lead to mergers. Specifically, from the number of parties with at least one entry in their lifespans (138 parties or $77 \%$ of the total number), only 41 or $30 \%$ were characterized by entry(-ies) only - and most of these entries were new mergers that were not preceded by coalitions. The rest of the parties with at least one entry exited coalitions (82 or 59\%) and/or consolidated them through mergers (41 or 30\%). Thus, the evidence indicates that electoral alliances either provide the means for achieving short-term electoral goals or serve as stepping stones for mergers.

These findings on the relationship between intra-coalition and inter-party cooperation and conflict support Hypothesis 1. However, low correlation between exit and mergers and especially between splits and all other forms of change contradict it. ${ }^{12}$ Thus, change can be understood as a multi-dimensional phenomenon that includes one or two loose dimensions of intra-coalition conflict and cooperation and inter-party cooperation, and a separate and distinct dimension of intra-party conflict.

\section{Understanding party change}

The existence of the multi-dimensional pattern of change suggests that the explanations of its individual forms are different. We view the substantiation of this argument through the development of elaborate theoretical frameworks and systematic empirical analyses of each form of change as a challenge to the future research that due to space constraints can not be fully addressed here. In this sub-section we make a more modest contribution by examining the association between change and three explanatory factors (Table 5) and

\footnotetext{
${ }^{12}$ We also note that weak correlation between splits and all other forms of change persists when analyzing parties in each country separately. Out of 53 individual correlation coefficients ( 5 in each country with the exceptions of Croatia and Hungary, where no mergers through consolidation were recorded), only four had absolute values above 0.4 .
} 
exploring country-specific patterns of change (Figure 3). Specifically, we examine the effect of party size because the literature on electoral coalitions and mergers (Golder, 2006; Ibenskas, 2016b,a) indicates that electorally vulnerable parties are more likely to coalesce with other parties. The second factor is closed-list electoral system. According to Ceron (2015b), it encourages splits by preventing rebellious politicians or factions from building a personal electoral following while remaining affiliated with their parent parties. At the same time, Ibenskas (2016b) argues that parties find it easier to reach electoral coalition agreements under closed-list systems because voters cannot disrupt the ranking of candidates established in the coalition agreement. Finally, the effect of the age of democracy is also studied here given that the level of party and electoral instability is often seen as a characteristic of the early years of democratic regimes (Kitschelt et al., 1999).

[Table 5 about here]

Table 5 shows that explanations of splits stand out in comparison to other forms of change. According to this simple correlation analysis, larger parties are more likely to split while entries, exits and mergers are more a characteristic of smaller parties. The strong relationship between party size and splits is an important finding that needs to be explored in greater detail in the future. It is possible that the voters of the parent party are more susceptible to the appeals of splinter parties, thus creating greater incentives for factions or individual politicians to found new parties. Moreover, in contrast to other forms of change, splits are only weakly associated with the age of democracy or closed-list electoral system. A comprehensive explanation of splits thus clearly needs to include many other factors not considered here, such as intra-party policy disagreements.

In line with the findings of the moderate or strong association between intra-coalition conflict and cooperation and new inter-party cooperation, we find that these forms of change are more likely when party's electoral support is low. This finding is not surprising given that coalescing with other parties is often a matter of electoral survival for small parties. 
The frequency of entries, exits and mergers also decreases somewhat as democratic regimes mature. However, while entries and exits are more likely under closed-list PR system, this electoral system is associated with the lower probability of the consolidation of coalitions through mergers. This supports the arguments in the literature that entry into coalitions is more likely under the closed-list system. An extension of this logic may also explain the effect of this factor on exits and mergers. Specifically, since under closed-list system the costs of founding new coalitions are lower, it is also less costly to dissolve an existing coalition by switching to a new alliance (instead of consolidating this coalition through a merger). In contrast, under open- or flexible-list system, while coalitions are less likely, once they are established, they are likely to be more durable and lead to full-fledged mergers. This factor may therefore may account for the lack of strong positive correlation between exits and mergers.

[Figure 3 about here]

Country-specific patterns reported in Figure 3 tentatively support these speculations about the causes of intra-coalition conflict and cooperation and new inter-party cooperation. A substantial variation in the frequency of these changes across time notwithstanding, their amount decreased in most countries since the 1990s. This trend is strongest in the Czech Republic, Estonia, Hungary and Slovenia, which, at least in the 2000s, were characterized by relatively limited party fragmentation, few new successful parties and relatively high electoral viability of established parties. Larger and more viable parties could benefit less from inter-party cooperation, thus leading to a lower number of electoral coalitions and in turn fewer opportunities for exits from them or their consolidation through mergers. The remaining countries in the region were characterized by relatively high levels of entry since their democratization. However, in the countries with closed-list electoral institutions especially Bulgaria, Croatia and Romania - these coalitions were less stable as shown by high frequency of exits and only few mergers in them. The countries with open- or flexible-list 
systems, in particular Estonia, Latvia and Poland, by contrast had more coalitions turned into mergers.

Figure 3 provides fewer insights about party splits. The variation in their frequency at the country level is limited. The trend of the decrease in time is also largely absent, possibly because the increase in party size created greater incentives for splits but this effect could have been countervailed by the increase in party institutionalization and ideological structuration. The lack of clear patterns in the frequency of splits further supports the notion that intra-party conflict is a development that is largely independent from intra-coalition and inter-party cooperation and conflict.

\section{Conclusion}

The third wave of democracy resulted in many countries in highly unstable parties and party systems. Not only have the levels of new party entry and exit been high, but the same applies for change in political parties resulting from splits, mergers, and the formation and dissolution of alliances. Indeed, the level of change has been so high as to make systematic comparisons between new and older Western democracies with stable parties and party systems difficult (Mair, 1997). Levels of party change in Central and Eastern Europe have decreased, but are still relatively high even twenty years after democratization. Party instability may have become a permanent feature of the politics in these countries that may also be a beacon of the future of party competition in older democracies (Deegan-Krause and Haughton, 2014).

This article advances our understanding of party change through a systematic analysis of its less researched forms - splits, mergers and electoral coalitions. It conceptualizes these forms of party change as manifestations of political conflict and cooperation within political parties, electoral alliances and the party system. Using a new dataset on party change in 11 Central and Eastern European countries, we find that intra-party conflict (manifested 
in party splits) occurs largely independently from other forms of change. The relationship between intra-coalition conflict (exits from alliances) and cooperation (mergers) and the formation of new alliances is moderately strong, especially when the unit of analysis is an individual party rather than a party-in-electoral-term.

Our findings have important implications. They indicate that, even if parties and electoral alliances are unstable, they, and not individual politicians, are key players in post-communist politics. Furthermore, the negative effects of party change on representation, accountability and government stability are possibly more limited than often argued as complex transformations that involve various types of change are not very common, at least not in a single electoral term. Finally, we suggest that aggregation of different types of change into a single index, while useful for a general assessment of party change, is of more limited value for understanding reasons behind instability. Instead, systematic analysis that distinguishes between conflict and cooperation at intra-party, intra-coalition and systemic levels can provide more useful insights.

Raimondas Ibenskas is Lecturer in Politics and International Relations at the University of Southampton.

Allan Sikk is Senior Lecturer in Comparative Politics at the School of Slavonic and East European Studies, UCL. 
Table 1: Conflict and cooperation within a single legislative term: tetrachoric correlation coefficients

\begin{tabular}{lrrrrrr}
\hline Variable & Split & Merger & Exit & $\begin{array}{r}\text { Exit } \\
\text { label }\end{array}$ & Entry & $\begin{array}{r}\text { Entry } \\
\text { label }\end{array}$ \\
\hline Split & 1.00 & & & & & \\
Merger & -0.04 & 1.00 & & & & \\
Exit & -0.04 & 0.23 & 1.00 & & & \\
Exit label & -0.07 & 0.31 & 0.87 & 1.00 & & \\
Entry & 0.02 & 0.17 & 0.44 & 0.30 & 1.00 & \\
Entry label & 0.04 & 0.17 & 0.31 & 0.49 & 0.81 & 1.00 \\
\hline
\end{tabular}


Table 2: Conflict and cooperation within a single legislative term: exploratory factor analysis of tetrachoric correlation matrix (varimax rotation)

\begin{tabular}{lrr}
\hline Variable & 1 & 2 \\
\hline Split & 0.02 & -0.08 \\
Merger & 0.16 & 0.28 \\
Exit & 0.41 & 0.78 \\
Label exit & 0.27 & 0.96 \\
Entry & 1.00 & 0.03 \\
Label entry & 0.80 & 0.27 \\
Initial eigenvalues & 2.70 & 1.20 \\
\hline \multicolumn{2}{l}{ Extraction method: maximum likelihood. }
\end{tabular}


Table 3: Conflict and cooperation across multiple legislative terms: Pearson correlation coefficients

\begin{tabular}{lrrrrrr}
\hline Variable & Split & Merger & Exit & $\begin{array}{r}\text { Exit } \\
\text { label }\end{array}$ & Entry & $\begin{array}{r}\text { Entry } \\
\text { label }\end{array}$ \\
\hline Split & 1.00 & & & & & \\
Merger & -0.12 & 1.00 & & & & \\
Exit & -0.07 & 0.18 & 1.00 & & & \\
Exit label & -0.06 & 0.10 & 0.72 & 1.00 & & \\
Entry & -0.01 & 0.37 & 0.69 & 0.52 & 1.00 & \\
Entry label & 0.00 & 0.17 & 0.59 & 0.67 & 0.68 & 1.00 \\
\hline
\end{tabular}


Table 4: Conflict and cooperation across multiple legislative terms: exploratory factor analysis (varimax rotation)

\begin{tabular}{lrrr}
\hline & 1-dimension & \multicolumn{2}{r}{ 2-dimensions } \\
\hline Variable & 1 & 1 & 2 \\
Split & -0.05 & 0.01 & -0.06 \\
Merger & 0.26 & 0.39 & -0.02 \\
Exit & 0.84 & 0.57 & 0.58 \\
Label exit & 0.79 & 0.31 & 0.95 \\
Entry & 0.79 & 0.97 & 0.23 \\
Label entry & 0.78 & 0.57 & 0.52 \\
Initial eigenvalues & 2.65 & 1.84 & 1.56 \\
\hline
\end{tabular}

Extraction method: maximum likelihood. 
Table 5: Correlation between party change and vote share, age of democracy and closed-list system

\begin{tabular}{lrrr}
\hline & Vote share & Age of democracy & Closed-list PR \\
\hline Split & 0.25 & -0.06 & 0.09 \\
Merger & -0.10 & -0.09 & -0.16 \\
Exit & -0.18 & -0.11 & 0.27 \\
Exit label change & -0.15 & -0.08 & 0.24 \\
Entry & -0.19 & -0.15 & 0.19 \\
Entry label change & -0.19 & -0.05 & 0.32 \\
\hline
\end{tabular}

Pearson correlation coefficents for vote share and the age of democracy and tetrachoric correlation coefficients for closed-list PR. 
Figure 1: Frequency of party change

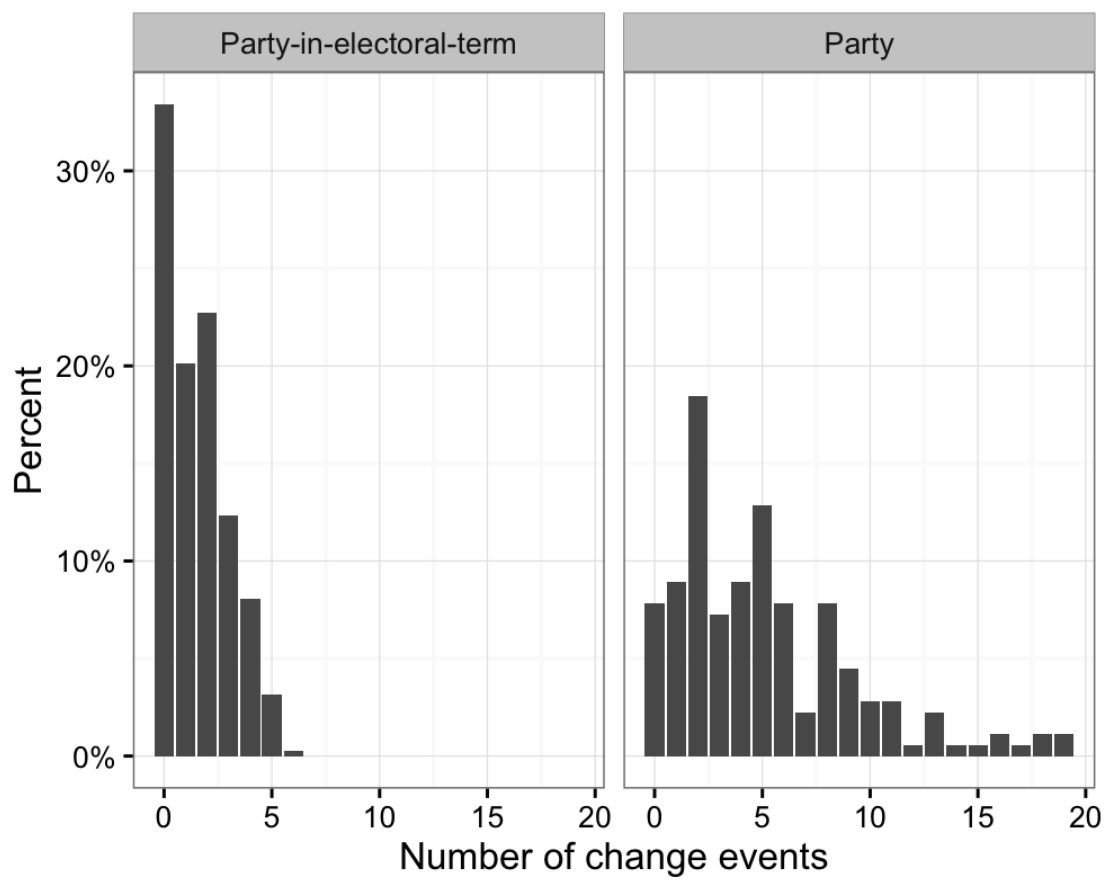

Note: Frequency of change per party includes only the parties that met the selection criteria for at least two electoral terms. 
Figure 2: Patterns of intra-party, coalition and party-systemic conflict and cooperation: Multiple Correspondence Analysis
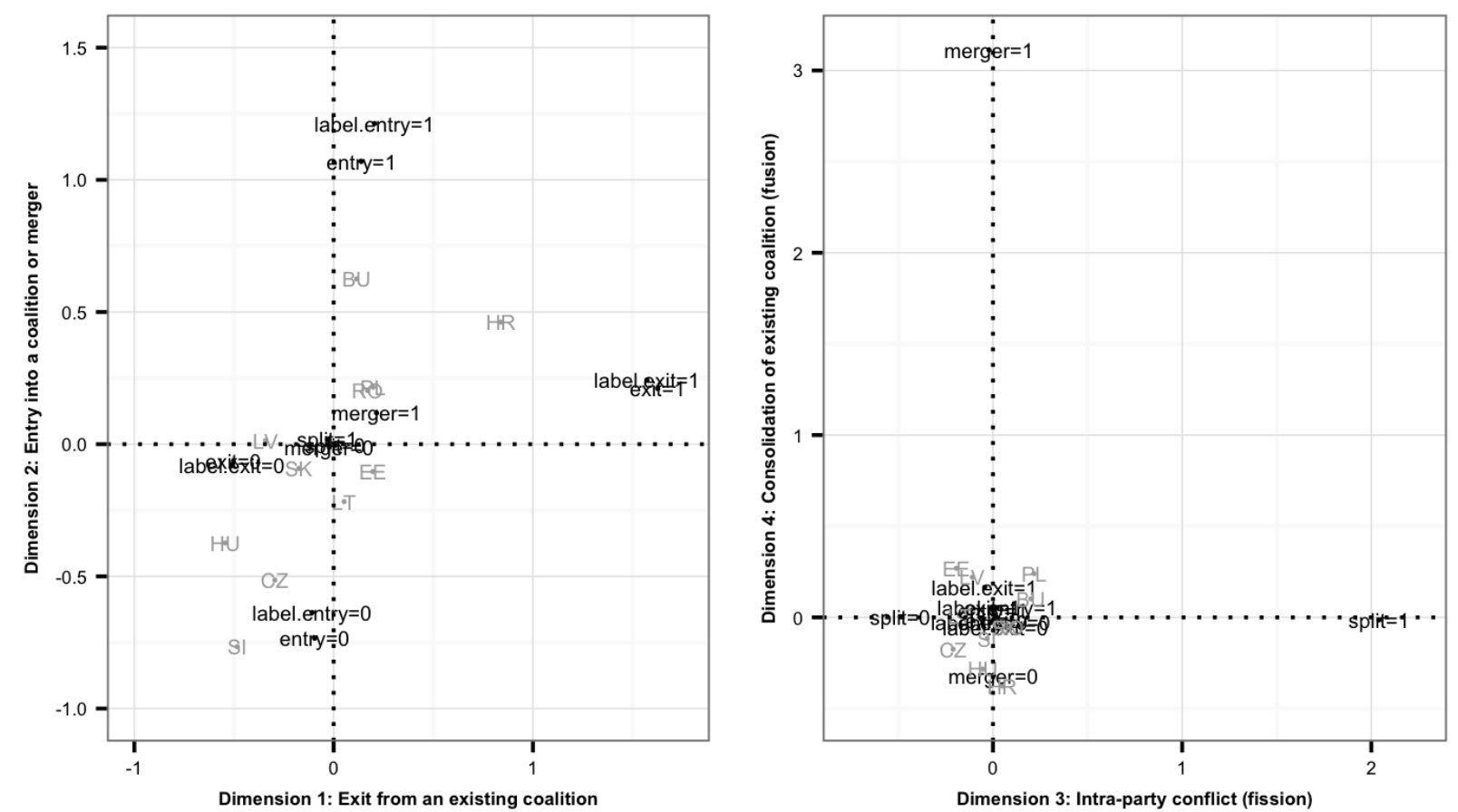

Note: 0 indicates the absence of a specific type of change and 1 indicates its presence. Abbreviations of country names indicate the location of the categories of the supplementary country variable. Varimax rotation as implemented in the 'PCAmixdata' package of the statistical environment $\mathrm{R}$ was applied to the original MCA solution (Chavent et al., 2014). 
Figure 3: Intra-party, intra-coalition and inter-party conflict and cooperation in Central and Eastern Europe
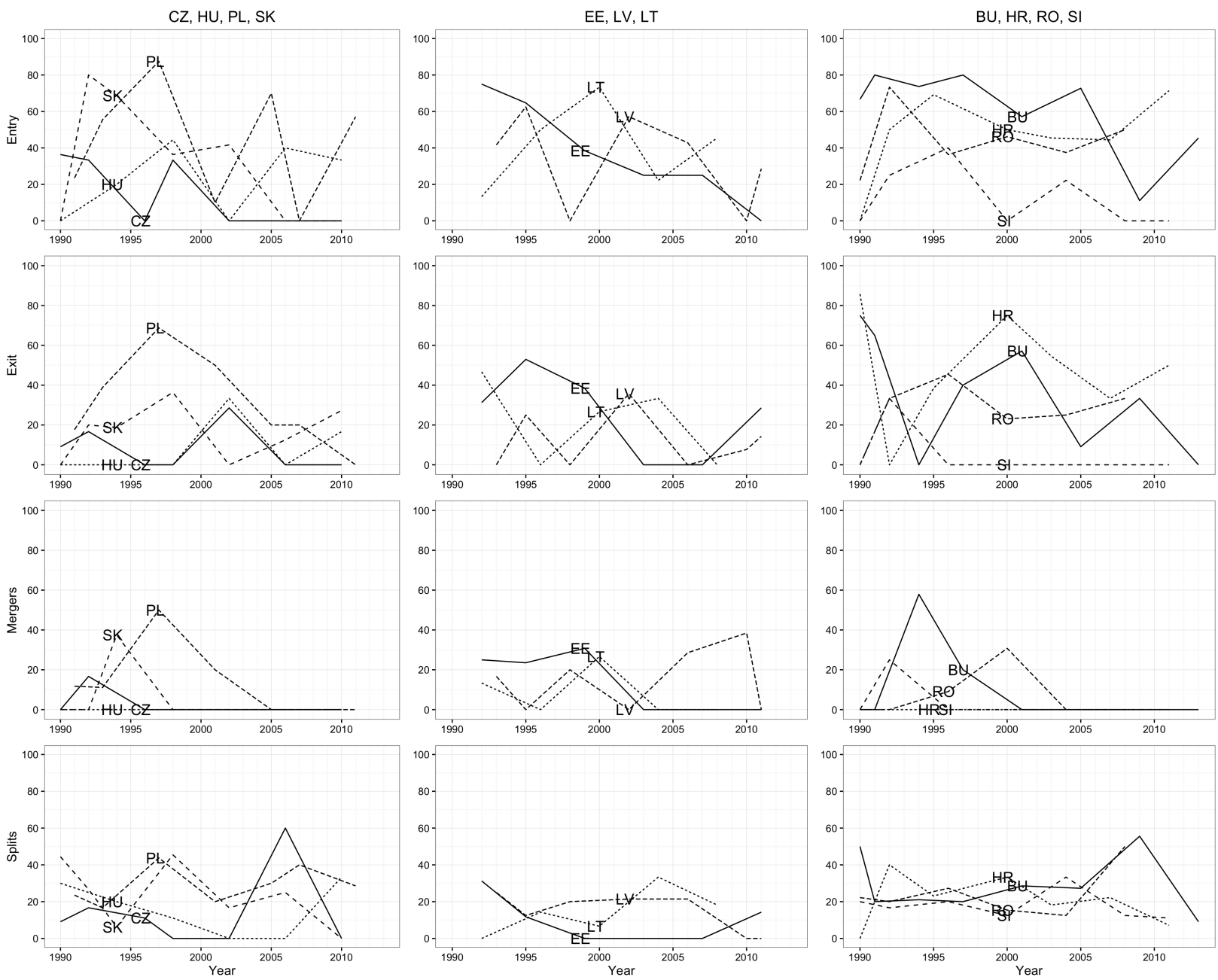

Note: the figure reports, for each electoral term, the share of parties that experienced four forms of change from the total number of parties in that term. The data for entry and exit label changes are not reported given their high correlation with entry to and exit from coalitions. 


\section{References}

Bågenholm, A. (2013). The electoral fate and policy impact of anti-corruption parties in central and eastern europe. Human Affairs 23(2), 174-195.

Bakke, E. (2010). Central and east european party systems. In S. P. Ramet (Ed.), Central and Southeast European Politics since 1989, pp. 64-91. Cambridge: Cambridge University Press.

Bakker, R., C. De Vries, E. Edwards, L. Hooghe, S. Jolly, G. Marks, J. Polk, J. Rovny, M. Steenbergen, and M. A. Vachudova (2015). Measuring party positions in europe: The chapel hill expert survey trend file, 1999-2010. Party Politics 21(1), 143-152.

Birch, S. (2003). Electoral Systems and Political Transformation in Post-Communist Europe. New York: Palgrave.

Casal-Bertoa, F., K. Deegan-Krause, and T. Haughton (2015). Splitting the difference: Measuring institutional and electoral volatility. Paper presented at the workshop "Party System Stability and Electoral Volatility: Its Measurement and Implications", University of Nottingham, February 26-27, 2015.

Casal Bértoa, F. and I. van Biezen (2014). Party regulation and party politics in postcommunist europe. East European Politics 30(3), 295-314.

Ceron, A. (2015a). Intra-party politics in 140 characters. to what extent does social media analysis provide information on intra-party dynamics? Paper presented at the Gothenburg Workshop on Intra-Party Politics, 17- 18 September 2015.

Ceron, A. (2015b). The politics of fission: An analysis of faction breakaways among italian parties (1946-2011). British Journal of Political Science 45(1), 121-139.

Chavent, M., V. Kuentz-Simonet, A. Labenne, and J. Saracco (2014). Multivariate analysis of mixed type data: The pcamixdata $\mathrm{r}$ package. arXiv. 
Deegan-Krause, K. and T. Haughton (2014). Eastern europe party development as a laboratory. Presented ACLS, EEPS, and University of Florida Workshop, January 9-11, 2014.

Desposato, S. W. (2006). Parties for Rent? Ambition, Ideology, and Party Switching in Brazil's Chamber of Deputies. American Journal of Political Science 50(1), 62-80.

Franzmann, S. T. (2011). Competition, contest, and cooperation: The analytic framework of the issue market. Journal of Theoretical Politics 23(3), 317-343.

Gherghina, S. (2014). Party Organization and Electoral Volatility in Central and Eastern Europe: Enhancing Voter Loyalty. London: Routledge.

Giannetti, D. and K. Benoit (2009). Intra-party politics and coalition governments in parliamentary democracies. In D. Giannetti and K. Benoit (Eds.), Intra-party politics and coalition governments, pp. 3-24. London and New York: Routledge.

Giannetti, D. and M. Laver (2001). Party system dynamics and the making and breaking of Italian governments. Electoral Studies 20(4), 529-553.

Golder, S. N. (2006). The logic of pre-electoral coalition formation. Columbus: Ohio State University Press.

Greenacre, M. (2007). Correspondence analysis in practice. Boca Raton: CRC press.

Greene, Z. and M. Haber (2015). Maintaining family ties: Preference divergence between sister parties. Paper presented at the Gothenburg Workshop on Intra-Party Politics, 1718 September 2015.

Hanley, S. and A. Sikk (2014). Economy, corruption or floating voters? explaining the breakthroughs of anti-establishment reform parties in eastern europe. Party Politics.

Hirschman, A. O. (1970). Exit, voice, and loyalty: Responses to decline in firms, organizations, and states. Cambridge and London: Harvard University Press. 
Hug, S. (2001). Altering Party Systems: Strategic Behavior and the Emergence of New Political Parties in Western Democracies. Ann Arbor: University of Michigan Press.

Ibenskas, R. (2014a). Activists or Money? Explaining the electoral success and persistence of political parties in Lithuania. Party Politics 20(6), 879-889.

Ibenskas, R. (2014b). Party organization, candidates and electoral competition after party splits. Paper presented at the 4th EPSA General Conference, Edinburgh, 19-21 June 2014.

Ibenskas, R. (2016a). Marriages of convenience: Party mergers in established and new european democracies. Journal of Politics 78(2), 343-356.

Ibenskas, R. (2016b). Understanding pre-electoral coalitions in central and eastern europe. British Journal of Political Science.

Kaminski, M. M. (2001). Coalitional Stability of Multi-Party Systems: Evidence from Poland. American Journal of Political Science 45(2), 294-312.

Kim, M.-S. and F. Solt (2015). The dynamics of party relabeling: why do parties change names? Party Politics.

Kitschelt, H., Z. Mansfeldova, R. Markowski, and G. Toka (1999). Post Communist Party Systems: Competition, Representation, and Inter-Party Competition. Cambridge: Cambridge University Press.

Kölln, A.-K. and J. Polk (2015). Is everyone enjoying the party? examining ideological incongruence among 10,000 swedish party members. Paper presented at the Gothenburg Workshop on Intra-Party Politics, 17- 18 September 2015.

Laver, M. and K. Benoit (2003). The Evolution of Party Systems between Elections. American Journal of Political Science 47(2), 215-233.

Lewis, P. G. (2000). Political Parties in Post Communist Europe. London: Routledge. 
Litton, K. (2015). Party novelty conceptualization and measurement of party change. Party Politics 21(5), 712-725.

Mair, P. (1997). Party System Change: Approaches and Interpretations. Oxford: Oxford University Press.

Marinova, D. M. (2015). A new approach to estimating electoral instability in parties. Political Science Research and Methods 3(2), 265-280.

Mershon, C. (2014). Legislative party switching. In The Oxford Handbook of Legislative Studies, pp. 418-435. Oxford: Oxford University Press.

Millard, F. (2004). Elections, parties, and representation in post-communist Europe. Houndmills: Palgrave Macmillan.

Olson, D. M. (1998). Party formation and party system consolidation in the new democracies of Central Europe. Political Studies 46(3), 432-464.

Pop-Eleches, G. (2010). Throwing out the bums: Protest voting and unorthodox parties after communism. World Politics 62(2), 221-260.

Rakner, L., L. Svasand, and N. S. Khembo (2007). Fissions and Fusions, Foes and Friends: Party System Restructuring in Malawi in the 2004 General Elections. Comparative Political Studies 40(9), 1112-1137.

Rohrschneider, R. and S. Whitefield (2012). The strain of representation: how parties represent diverse voters in Western and Eastern Europe. Oxford: Oxford University Press.

Rose, R. and N. Munro (2003). Elections and parties in new European democracies. Washington, D.C.: CQ Press.

Rose, R. and D. C. Shin (2001). Democratization backwards: The problem of third-wave democracies. British Journal of Political Science 31(2), 331-354. 
Rovny, J. and J. Polk (2015). Fluid parties, fickle voters, fixed spaces: Assessing the stability of party competition in eastern europe. Paper presented at the 22nd International Conference of Europeanists, Paris, July 8-10 2015.

Scarrow, S. (2015). Beyond Party Members: Changing Approaches to Partisan Mobilization. Oxford: Oxford University Press.

Sikk, A. (2005). How Unstable? Volatility and the Genuinely New parties in Eastern Europe. European Journal of Political Research 44(3), 391-412.

Sikk, A. (2012). Newness as a winning formula for new political parties. Party Politics 18(4), $465-486$.

Spirova, M. (2007). Political parties in Post-Communist Societies: Formation, Persistence, and Change. New York: Palgrave Macmillan.

Szczerbiak, A. (2001). Poles together?: the emergence and development of political parties in postcommunist Poland. Budapest: Central European Univ Press.

Tavits, M. (2013). Post-Communist Democracies and Party Organization. Cambridge: Cambridge University Press.

Van Biezen, I., P. Mair, and T. Poguntke (2012). Going, going,... gone? the decline of party membership in contemporary europe. European Journal of Political Research 51(1), $24-56$. 